\title{
THE SUSTAINABILITY OF FLORA, FAUNA AND GEOMETRIC MOTIF DESIGNS AMONG BATIK TULIS MANUFACTURERS IN KLANG VALLEY
}

\author{
Ahmad Hakim Abdullah ${ }^{*}$, Mohd Azhar Samin ${ }^{2}$ \\ 1 Department of Art \& Design, Universiti Teknologi MARA,Shah Alam,Malaysia \\ Email: hakimabdullah08@gmail.com \\ 2 Department of Art \& Design, Universiti Teknologi MARA,Shah Alam,Malaysia \\ Email: azharsamin64@gmail.com \\ Corresponding Author
}

\section{Article Info:}

Article history:

Received date: 20.04 .2020

Revised date: 26.04 .2020

Accepted date: 06.05.2020

Published date: 10.06.2020

\section{To cite this document:}

Abdullah, A, H., \& Samin, M. A. (2020). The Sustainability of Flora, Fauna and Geometric Motif Designs Among Batik Tulis Manufacturers in Klang Valeey. International Journal of Heritage, Art and Multimedia, 3 (9), 11-24.

DOI: $10.35631 /$ IJHAM.39002.

\begin{abstract}
:
The purpose of this research is to find out the development of the batik tulis industry in the Klang Valley from the 1970s until 2018. It aims to study the design and identity of the batik tulis motif and patterns. This research used several methods and approaches for data collection which consisted of interviews, observations, and photo documentation. Three batik tulis manufacturers in the Klang Valley have been selected for this study. The data collected were then analysed using an analytical design approach. The findings showed that each manufacturer of batik tulis has exclusivity in terms of its subject matter as well as assertions in the patterns and designs used. The development of the batik tulis industry has changed in terms of designs according to the demands of batik consumers themselves who prefer differentiation in the design concept of batik products. Most of the batik products in the Klang valley are more focused on the concept of modern and contemporary designs for the sustainability of these batik motif design.
\end{abstract}

Keywords:

Klang Valley, Batik Tulis, Motif Design, Manufacturer, Sustainability

\section{Introduction}

Batik in Malaysia does not have the unique identity as compared to the Indonesian batik. Essentially, the application of the batik tulis is widespread among the Malay community. Batik tulis has evolved through the years but need to have a specific identity that provides its value for modernity. According to Sasaliza Mohd Sirin (2017), not many people in the Klang Valley know that they have their own batik industry compared to folks in Kelantan and Terengganu. 
Batik in the Klang Valley tend to bear more traditional features such as flora and fauna, and abstract motifs, even though the time has changed. In addition, those who live in the city do not get extensive knowledge about batik tulis. Currently in Malaysia, the number of people wearing batik has reduced because not many are making it a practice to wear traditional clothing. This is especially true in the Klang Valley, particularly the federal district. In an effort by the government to promote batik, the practice of wearing batik is made compulsory on every Thursday, in the government sector. Hence, the purpose of this research is to find out the development of the batik tulis industry in the Klang Valley and study the evolution of the motifs and patterns used since the 1970s.

\section{Literature Review}

The word batik has two meanings. The word originates from Indonesia and it means producing coloured patterns on white textiles by dyeing them. The second meaning is a white cloth that is decorated with the use of wooden, copper or iron blocks, and for the areas that are to be left undyed, wax, rosin or resin is applied. Batik cloths are generally made out of cambric, lawn, or voile. The art of batik is one of the cultural roots that forms the identity and raises the dignity of any given nation that batik has found a home in. The batik industry is one of the small to medium industries that form the backbone of the country. The purpose of innovating the local batik industry is to give it a chance to compete at a global level (Batik Drawn In wax, Itie Van Hout, 2001).

There are many countries where batik has found a home in. For instance, the art of batik has been in Egypt and Persia for approximately 2000 years, whilst in Japan and China, it was first used in the 7th century. It has also long-existed in Indonesia and has enjoyed growth in Malaysia since it surfaced in the country over a century ago. Kelantan and Terengganu are pioneers in the Malaysian history of batik. It began in Kota Bharu, Kelantan in 1914 when knowledge of the technique was learned in Java and brought over. Batik cloth in Malaysia was created by Haji Che Su and his friends when they worked at batik Pelangi Enterprises, which was located at Jalan Gajah Mati, Kota Bharu. The batik industry also developed in other states in the country (Dr.Arbaiyah Aziz, 2008).

According to (Zarlina Zamri et al., 2017), the basic element of batik tulis is practiced in the traditional batik village where batik practitioners produce flora, fauna, geometric and abstract motifs as a result of their meticulous observation of nature as well as its surroundings. Nature and its myriad of living things become the source of inspiration to batik practitioners to communicate through their batik tulis art, of the exquisiteness of God's creations. Thus, to produce craft materials such as batik, undeniably the practitioners require new ideas especially in applying the canting techniques to produce batik: it requires an integration of skills such as psycho-motor, cognitive and affective (Bloom,1956). Then, idea generation is crucial to practitioners in exploring a myriad of motives on canvas. 


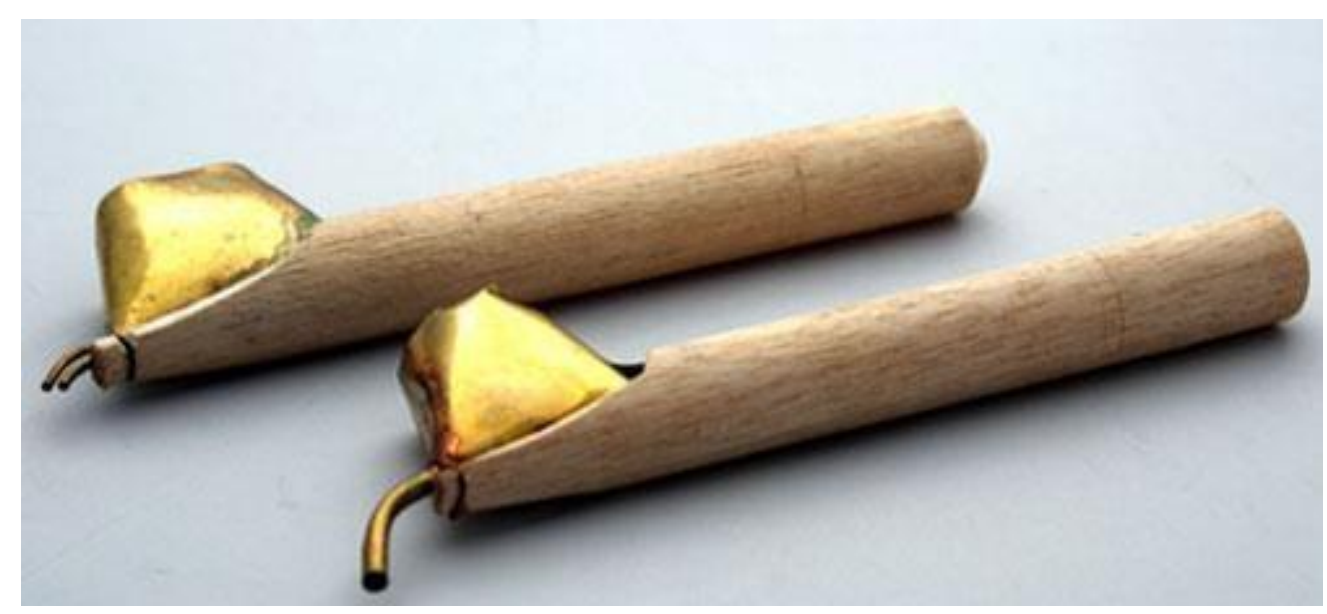

Figure 1: Batik Tulis Canting In 1999 (Khamis,25 Mei, 2018)

Furthermore, in the Klang Valley, wood is carved for house decoration or batik tulis (canting.). Thus, the philosophy is understood by viewing the motif of the philosophy. This means the motif of the woodcarving is similar to the traditional motif of batik tulis. In addition, the inspiration for motif making is usually associated with nature where they attempt to immortalize God's beautiful creation in their masterpieces. Thus, the reason most of the researcher's focus on the main motive of flora, fauna, geometric and abstract designs.

According to Qua (2007), the batik tulis (lukis, canting or Conteng) involves the process of boiling wax to be liquid for the purpose of sketching and colouring the patterns and motifs designed. In the $20^{\text {th }}$ century, the making of Malaysian batik had introduced a new tradition to the Malaysians, whereby the batik types and motifs became the national symbol to retain its original value, to be protected and inherited by the society that understands its values. Moreover, the awareness of the significance of batik sustainability and preservation has contributed to the rapid progress of batik tulis. Besides, the Malaysian batik is an industrial art, which is a vital symbol that was completely threatened, and now protected by the government as all Malaysians have a similar understanding of batik tulis.

Table 1: Differences Between Traditional And Modern Batik

\section{Batik Tulis}
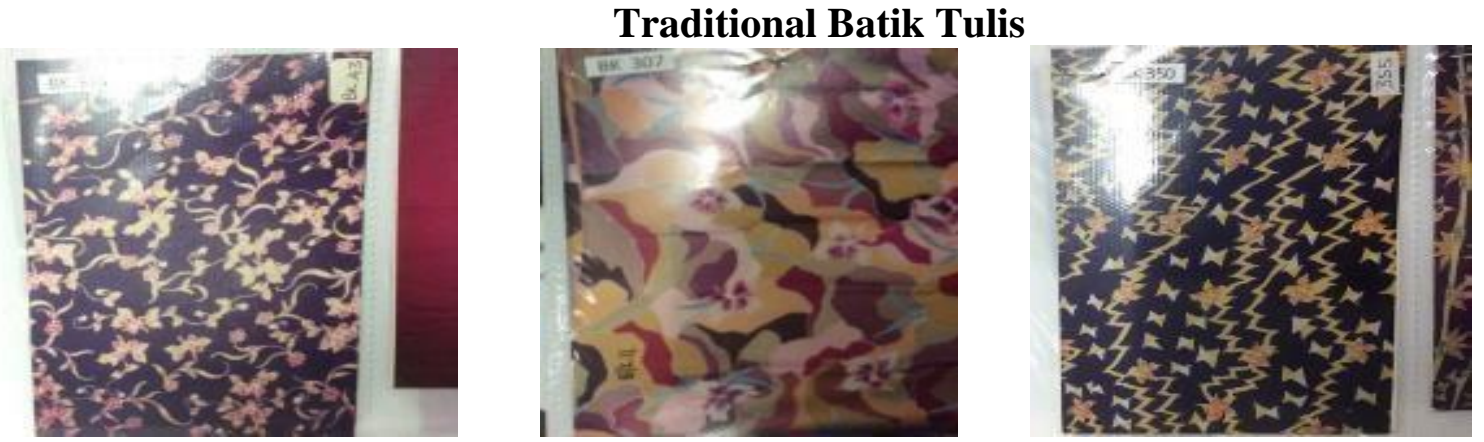

Malaysian Batik Tulis produced in

Malaysian Batik Tulis in 1980s

Malaysian Batik Tulis it the1980s

1970 s

(Sal April 7,2018) 


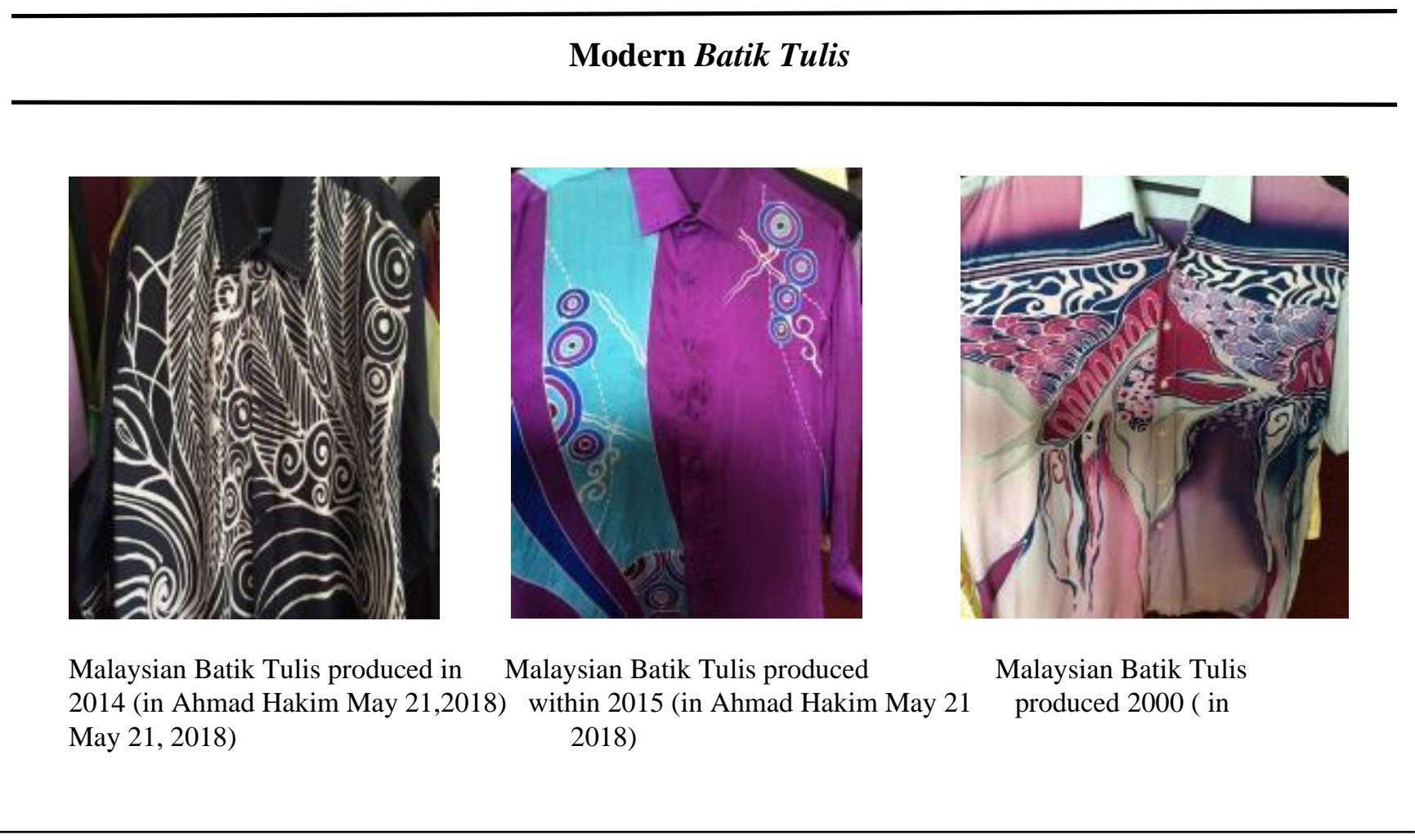

Table 1 shows the differences between the traditional and modern batik tulis in Malaysia as seen above. The batik tulis differs in terms of the motives and design of the pattern and this has changed from the 1970s to 2018. The motives and design of the batik pattern among the Malaysian batik tulis producers have been transformed according into a more contemporary concepts of the younger generation.

Overall, the motif creates the design of batik tulis and results in certain characteristics that can be identified as an identity that has a certain philosophy behind it. The above review provides strong justification for the reason why flora, fauna and abstract should be one of the identities in the future of batik tulis. This spirit needs to be instilled as an awareness within maker and the Malay society as well. This study aims to preserve and sustain the traditional motif of flora, fauna geometric and abstract.

Perbadanan Kemajuan Kraftangan Malaysia (2017), defines batik as a process of producing cloth by using applied wax techniques to produced patterns that are then buried with a variety of interesting colours. The pattern of patterns and the use of new materials has further remodelling in the batik production. Generally, the patterns created in the Klang Valley are developed for the world of international fashion. Usually of the patterns and motifs of the batik are inspired from nature such as flora and fauna which are then bundled with geometric or abstract patterns. Based on the argument, batik in Malaysia has its own concept and definition which symbolizes the Malay culture and identity.

Summer (2008), defined the meaning sustainability can be defined as the action to make something continuously to exist, happen, or maintain for a period of times. In addition, sustainability is a process where sustainability (environment, social and financial) is combined into a system from idea generation obtained from research and development (R\& D) and 
commercialization. This applies to products, services, technologies, new business and organization model (Charter \& Clark: Shuib \& Enoch,2013).

\section{Research Methodology}

This research employs a qualitative approach with selected methods such as library research, fieldwork, and interviews. Preliminary interviews were completed with 3 local batik tulis practitioners from various states. For post-interview, open-ended questions with formal indepth untrusted interviews were carried out with local batik tulis manufacturers. Curators from the Klang Valley and a selected academician who is a batik tulis expert were also interviewed to achieve the first objective. Next, to complete the second and third objectives, the researcher used formal close-ended structured interviews with a group of batik tulis experts and batik tulis consumers. Convenience sampling was employed due to a small population in the urban area. Thus, research employs a qualitative approach with selected method such as library research, fieldwork and interviews.

The qualitative method was used to determine the motifs of batik tulis which is flora, fauna and geometric design concepts based on the techniques of observation and sampling. An observation was carried out at the Kuala Lumpur Craft Complex in Jalan Conlay, to record the activities at Master Wan Batik company, Abas Sal Batik company, and Chanting Creation. Then, observation continues through studying catalogues and websites. Through these observations, the researcher was able to be more selective in choosing the batik tulis products that are suitable to be analysed. For the methodology, the researcher has used the typography process in order organise the data systematically. A total batik tulis practitioners from Klang Valley states in Malaysia have been interviewed. In all, 10 questions have been asked to each selected manufacturer manager, of which 3 about demographic background of all respondents, 7 about the motifs regarding the identity of batik tulis. Overall, the outcomes have provided answers to the research questions of this study.

\section{Data Analysis}

Three producers of batik tulis in the Klang Valley have been chosen to participate in the study, namely the Master Wan Batik, Abas Sal Batik, and Chanting Creation. The Master Wan Batik has started manufacturing batik since the early 2000s. Master Wan Batik acts as manufacturer, supplier, and dealer. This batik tulis manufacturer is one of the active companies in the Klang Valley and is more focused on the production of batik block and batik tulis products compared to stencils. The second batik manufacturer who participated in the study was Abas Sal Batik which has been established in the year 1999. They produce many batik tulis products such as cloth products, installed bracket button shirt with a more traditional concept of identity, and use designs more to flora motives with compact arrangement. The third company was the manufacturer of the batik tulis products known as, Chanting Creation, who is a manufacturer with modern contemporary concept. The company's identity is characterized by abstracts, flora, and fauna motifs with modern concepts. Chanting Creation batik tulis products include cloth robes and Men T-shirts. Design changes were made in particular to meet the higher demands of customer needs and also the changing of time.

Overall, the characteristics of the sampling were based on their expertise in batik tulis from different places located in the Klang Valley. This research uses the Zakaria Ali approach which has five theoretical elements, finesse (berhalus), usefulness (berguna), unity (bersatu), contrast (berlawanan), and symbolism (berlambang). The conceptual framework contains global themes such as uplifting appreciation and awareness of local motives and designs of batik tulis identity. All these batik studies will follow the theory founded by Zakaria Ali. 


\section{Results and Discussion}

\section{Master Wan Batik Tulis Collection}

Table 2: The Classification Tables For Batik Tulis Master Wan Batik

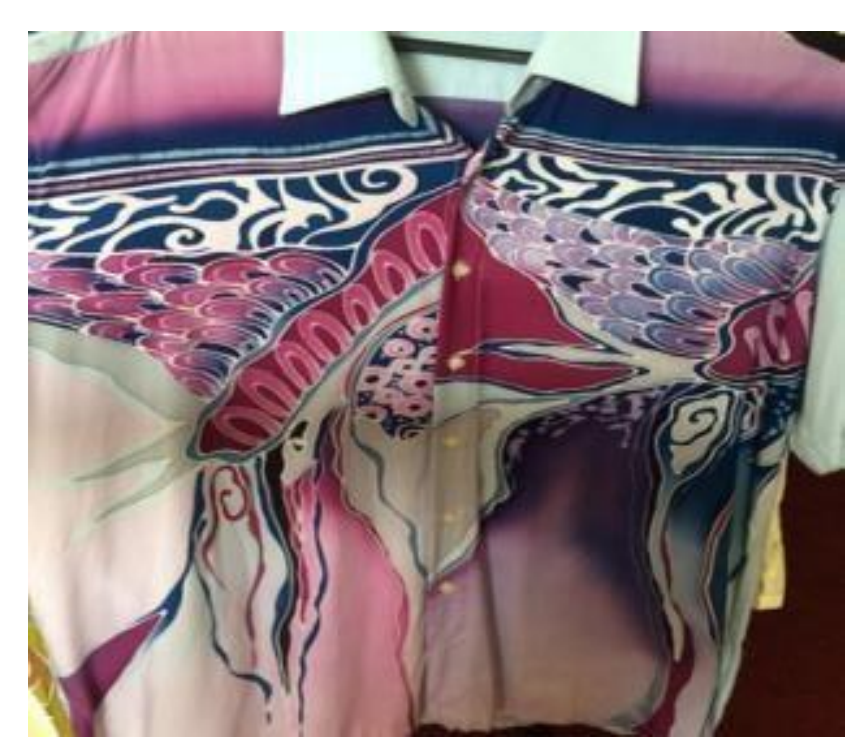

\section{Classification :Fauna}

English Name: Peacock

Malay Name: Burung Merak

Year: 2000

Owner: Wan Makhtar

Placement: Body of Cloth

Function: Education and food

Source from Wan Makhtar (2018), Master Wan Batik at Jalan Ambar, Dengkil,Selangor

Table 2 above is a description of how batik designers consuming peacock (Burung Merak) motive artwork above a batik tulis fabric. Peacock (Burung Merak) also has an interesting pattern that is the pattern of fur with the colours blue and red. In addition, the peacock is also a symbol of exotic birds or subject matter that is found in Malaysia and countries such as Bangladesh, India and others. This pattern of flapping peacocks was reworked from original motives. Designers have been making different sizes between canting outlines motif with lines in the motif. This is because the size of the canting sizes used showed what the designer wants to emphasize in batik tulis. According to the statement by Zakaria Ali (1993), in the production of this art, many things should be taken into consideration to achieve fine arts such as form and shapes, structures, unbalances compositions, colours and themes. In these batik tulis designs, they explained that the designers emphasised the elements of composition between the left and the right at the figure section above. This motif shares the characteristics of the function in education. Thus, peacock has been used in the batik tulis motif because they tried to preserve uniqueness these fauna motifs namely big bird peacock motif combined with dull colours. 


\section{Table 3: The Classification Tables For Batik Tulis Master Wan Batik}

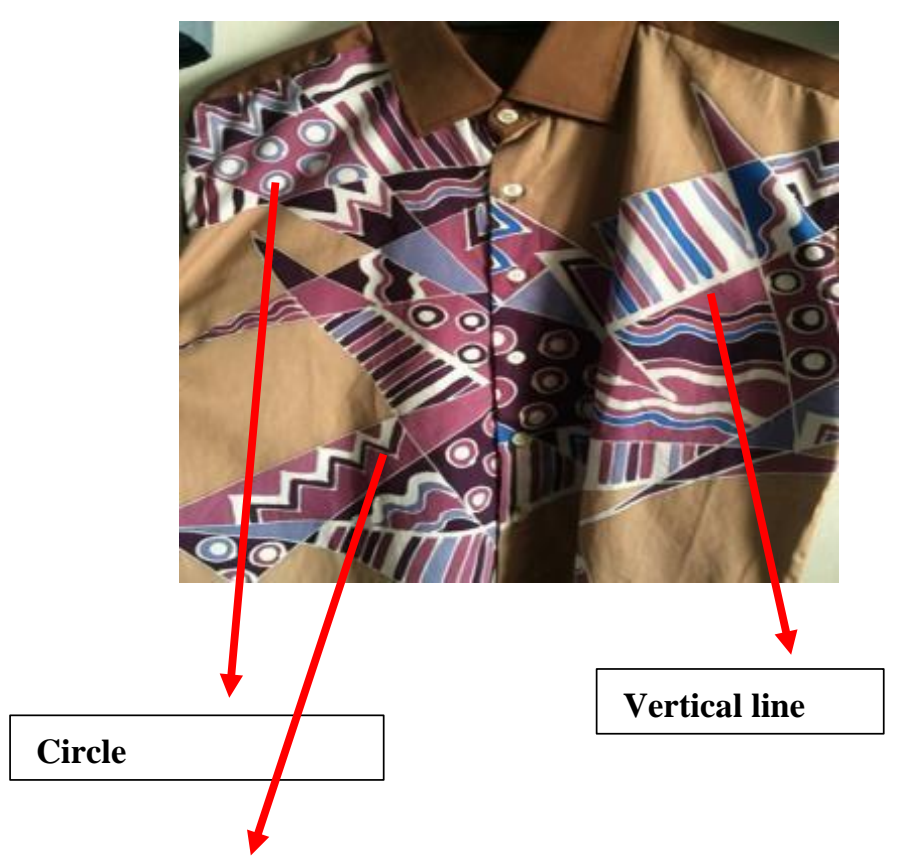

Classification: Geometric

English Name: line

Malay Name: Garisan

Year: 2008

Owner :Wan Makhtar

Placement: Body of Cloth

Function: Education, religious

\section{Triangle}

Source from Wan Makhtar (2018), Master Wan Batik at Jalan Ambar, Dengkil,Selangor

Table 3 shows the batik tulis patterns and design which are more inclined towards geometric shapes, such as triangles, circles, straight lines and undulating lines. Selection of the shapes as the basic structure depends on the final function either as a decoration or placement.

According to Abdullah and Nakula's concept about God and the universe (1978), a circle is the essence of Allah. The circle is based on the shape of the moon that symbolizes the 'heart', whereas the sun symbolizes 'essence of God'. Most of his concepts begin with the circle creating the symbol of the lotus flower, the moon and the Wau (traditional kite). This clearly states that using the shape of the circle as a basic shape has its reasons and meaning in the concept of God in Malay art interpretation. Keith Critchlow (1976) in his research about Islamic patterns, based on the analytical and cosmological approach, has defined that a circle is the basic shape for other polygon such as square, hexagon, triangle, and other polygon shapes. The triangle represents the symbol of human consciousness. It is commonly used as a base for brackets (sesiku) reducing the sharp 90-degree angle, a principle of opposites (berlawanan) in Malay aesthetics.

In addition, these patterns of batik tulis also have straight and corrugated lines. These geometric motifs require a high level of patience to create by using the canting. This is because the geometric shapes require high level of concentration to produce. In the products manufactured by Master Wan Batik, their batik designers use canting line in the style of straight lines, as well as round, corrugated line. 
In the production of batik tulis T-Shirts, designers use more geometric shapes to make various patterns. However, it is more independent, and more than not limited to the pattern of flora and fauna, and the pattern uses more geometric shapes with cold or bright colours. According to Moore (1942), he suggested that the value of the beauty of the form can be measured by angle, such as objective and subjective angles. From the objective corner, the evaluated features include a form of object or work. The form works are more focused on real aspects based on design elements such as colours, outer shapes (shape), lines, texture, and soon. Overall, these traditional batik tulis used bright and striking colours especially in pattern and geometric motifs.

\section{Abas Sal Batik Collection}

Table 4: The Classification Tables For Batik Tulis Abas Sal Batik Collection

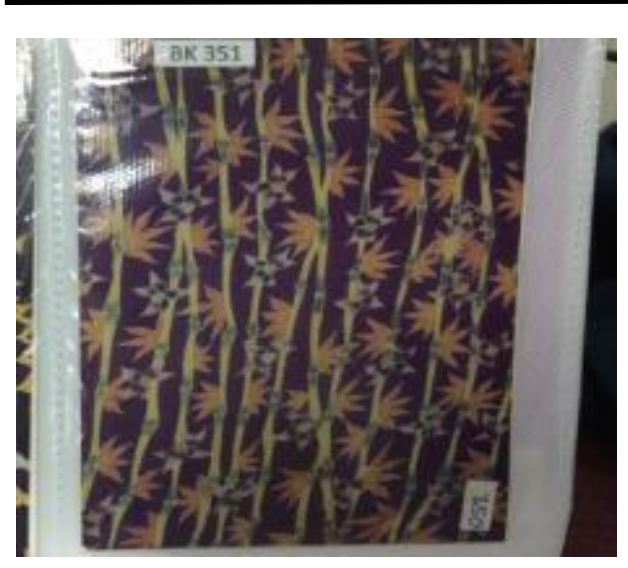

\section{Classification: Flora}

English Name: Bamboo

Malay Name: Buluh

Year: 1980

Owner: Abas

Placement: Body of Cloth

Function: decoration and education

Source from Abas and Salmah Batik (2018), Kampung Padang Balang.Kuala Lumpur

Table 4 shows how this designer consuming batik tulis theme of bamboo (buluh) as an idea in the motive of batik tulis around the 1980s. This batik tulis is painted with modern colours and still sustains the traditional concept that is a repetitive design. Designers use the subject matter as it is easy to find, has a unique feature, and is distinctive in terms of appearance and attractive to be used as motifs in batik tulis at Abas Sal Batik Collection. In this subject matter of bamboo (buluh), these batik tulis motifs support the whole space in this batik. Colours used in the batik creation are also modern colours. The background colour is darker than the colours of the motifs that would give a better impact on the subject matter that used this. The colours used are purple, orange, green, and yellow, which are namely modern colours. Thus, bamboo is the nature source of god's invention plants that to give the function to use decoration and various multi-purposes for human.

In the work of batik tulis at Abas Sal Batik, it is more susceptible to more organic ideas of plants, which are abundance around us and is easily observed in our environment. This was also explained by Zakaria Ali (1987), who said that the natural ingredients of nature are the most important level of experience for the Malays. The ironic and beautiful nature of the environment became the attraction to the Malay artists to make it necessary for their needs and the way of doing things. The art produced is something that has an aesthetic value. The Copyright (C) GLOBAL ACADEMIC EXCELLENCE (M) SDN BHD - All rights reserved 
aesthetics value produced in the crafts of these Malays is subtle, useful, united, fighting, and applies the principles of the emblem, so that they can provide satisfaction to the designer of crafts and art.

Table 5: The Classification Tables For Batik Tulis Abas Sal Batik Collection

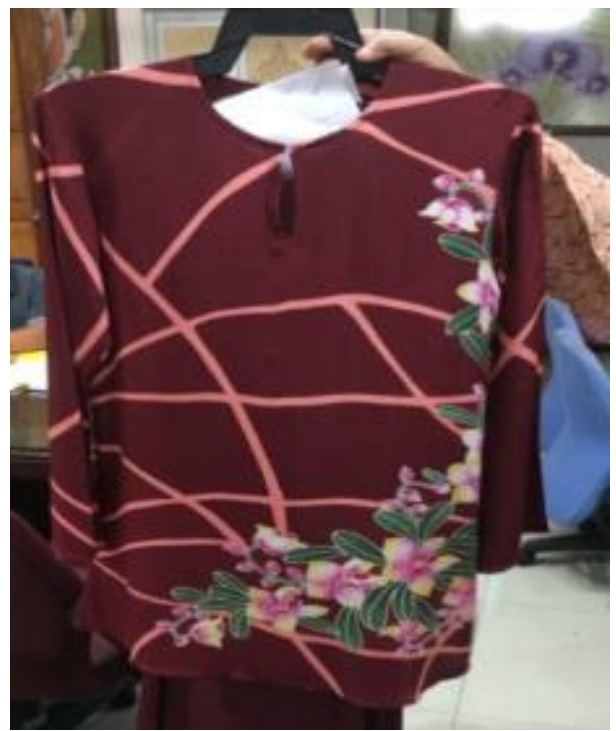

Classification: Flora

English Name: Orchid Flower

Malay Name: Bunga Orkid

Year: 2015

Owner: Abas

Placement: Body of Cloth

Function: Education, medicine and accessory

Table 5 shows the design of batik tulis at Abas Sal Batik which is highlighting the concept of flora orchid flower but have been modernized by the use of contemporary colours. In the meantime, this batik tulis design at this bracket has been used on a shirt with brush techniques which are then used as a background on the fabric of this baju kurung. The designer applied Abas Sal Batik popular colours such as purple, yellow, green, pink, and dark red. Batik tulis on this fabric use composition layouts at the bottom of the subject matter of this flora design. The size of the Orchid flowers is also different and are arranged closely together. Thus, the element of plants and cosmic are integrated in a motive as the manifestation of nature's beauty and the great creation of Allah.

Batik tulis at Abas Sal Batik such as this one has a pattern of orchid flowers, which symbolizes the softness that reflects the same pattern of approach in our daily lives. According to Ku Zam Zam (1984), the surroundings is something that is an important resource in the production of the Malay motives. Most of the patterns produced by Malays usually have a connection with their lives and the environment. In relation to this, the production of Malay crafts is less than a sense of awareness of the needs of applied and aesthetics of life. It is therefore imperative that the idea of the environment has also played an important role in valuing flora and fauna as long as it is still an inspirational source for the designers and their artwork in batik tulis. Overall, orchid flower as well used as medicine in human life being. 


\section{Chanting Creation Collection}

Table 6: The Classification Tables For Batik Tulis Chanting Creation

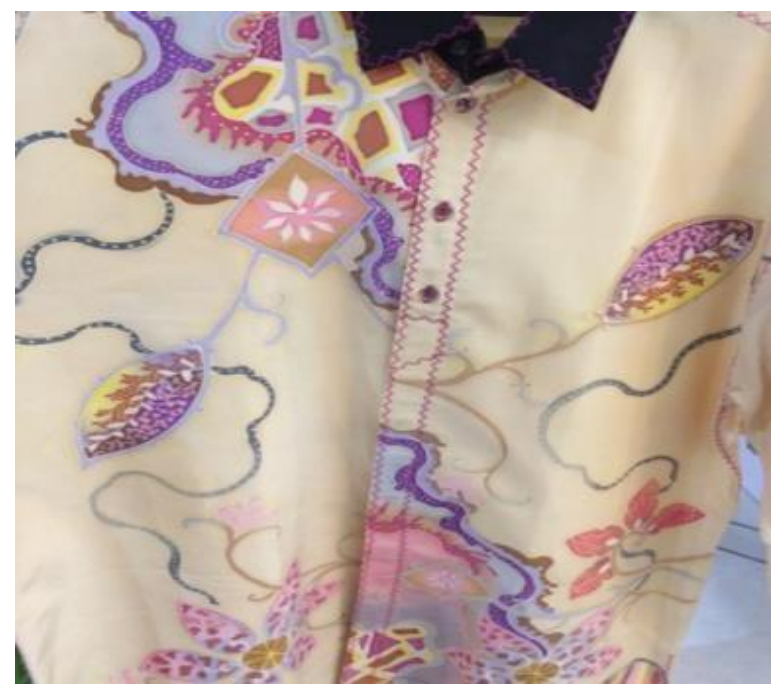

Classification: Flora

English Name: Ketam Guri flower

Malay Name: Bunga Ketam Guri

Year: 2005

Owner: Mohd Faisal

Placement: Body of Cloth

Function: Education, decoration and accessory

Sources from Mrs Faisal, Chanting Creation (2018)

Table 6 above shows how the designer appropriated a batik tulis inspiration from the subject matter of Ketam Guri flower, showing the beauty of these flora to be used as motifs in these batik tulis on a cloth shirt. The designer also used modern colours in this batik tulis. The colours in this batik tulis are more emphasized colours unlike the traditional batik but these are contemporary colours. The designer used the subject matter as the main motif highlighted in this Ketam Guri flowers batik, which symbolised the Semangat or spirit. Colours used were purple, orange, brown, red and blue. In this type of batik tulis design, the use of pastel colours as well as leaf motifs or flora provide a sense of peace and the colours affect the psychology of the batik lovers and their favour. Pursuant to the statement by Pooke \& Witham (2010), in the art of painting, visual elements including lines, shapes, colours and tones are embodied from the effects of the technique and media used by the artist. Additionally, the motives are designed to evoke certain feelings among observers such as the purpose of an artist to arouse a certain kind of action (Collingwood, 1984). Meanwhile, these batik tulis motifs to show these modern worlds still relevant by used Ketam Guri (Bunga Ketam Guri) is traditional whose many philosophies and decoration nowadays. 


\title{
Table 7: The Classification Tables For Batik Tulis Chanting Creation
}

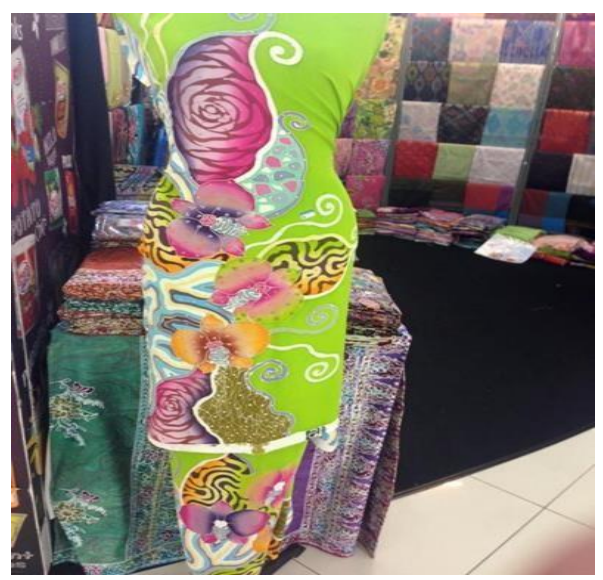

\author{
Classification :Fauna \\ English Name: Butterfly \\ Malay Name: Rama-rama
}

Year: 2014

Owner: Mohd Faizal

Placement: Body of Cloth

Function: Education

Table 7 presents the unique design when designers revenue their inspiration from the subject matter of butterflies fauna in batik motive as presented in this collection from Chanting Creation made in 2014. The batik design looks modern with the use of modern colours with different tones on the subject matter of this butterfly. Then, the composition of the supporting motifs also plays a role to fill in the spaces to complement the main motive in this batik tulis. The colours used are harmoniously blended to create a batik tulis with a unique identity using the motifs of flora in many variations, in the form of a modern and contemporary design. The designer also generates the motive by sustaining the concept of flora and fauna but maintaining a focus on a modern design.

According to Rabiatuladawiyah Mohd Kari et al. (2018), the philosophy of fauna in batik artwork has been widely affected by the effects of globalization. Globalization has affected the basic meaning of values, metaphor, and symbol, in a Malay attire such as batik. Furthermore, butterflies, bees, birds, cocks, peacocks, deer, and mousedeer motifs are other important subject-matters included, whereby the motives have been changed in the fauna style that had symbolic values.

In the $20^{\text {th }}$ century, the making of Malaysian batik had introduced a new tradition to the Malaysians, whereby the batik types and motifs became the national symbol to retain its original values that is to be protected and inherited by the society that understands its values. Moreover, the awareness of the significance of batik tulis sustainability and preservation has contributed to the rapid progress in the creations of batik tulis. The batik manufacturers play an important role in guarding this vital symbol that was completely threatened. Now the batik industry is protected by the government as all Malaysians have a similar understanding of the value of batik tulis. 


\section{Conclusion}

Overall, this research has many positive acceptances and awareness from all parties involved on the significance of craft to the social pattern and norms, batik tulis is seen as able to be contributed to the development of future generation that is knowledgeable, admires cultural inheritances, competent, creative and competitive. This research also had an association with the goals in the Eleventh Malaysia Plan, (RMK-11) on 2016-2020. It recommended that future researchers study the identities of batik tulis in each district in Malaysia. The contribution of this research will serve as an important design bank for manufacturers of batik tulis to come up with new designs with reference to the traditional motifs.

This research has recognized and categorized the traditional motifs and the new motifs of batik tulis using the flora, fauna and geometric designs in the typology analysis to uphold its identity as a Malaysian production. Based on the findings, it can be concluded that the current local batik tulis does not have a strong identity in flora, fauna, and geometric designs. The most vital findings of this study is that the bird (peacock), insect (butterfly), flower (bunga Ketam Guri), and geometrics such as vertical line, circle, and triangle are the dominant types of flora, fauna and abstract that are used as a contemporary batik tulis design and can be used to form the guidelines in designing motifs of a batik tulis identity in Malaysia. As long as the batik tulis makers observe the requirement of Islam that prohibit real-life artwork, there should not be any issues. Nonetheless, the traditional motifs will be sustained and the lessons in producing batik will spread from time to time.

This research identified the unique identity and concept of batik tulis at three premises of batik in the Klang Valley which have been practiced since the 1970s. Batik tulis at these three premises have a distinctive identity in terms of concepts, including the use of colours, fabric type, layout, and composition of the subject matter. All of the findings were analysed using the theory approach of design analysis, and interpretation. Production of batik tulis in the Klang Valley has evolved from traditional patterns to modern concepts of identity. All three companies' batik tulis have similarities in this progression of concepts from the 1970s to 2000s. Results from the study have also uncovered the identity of the batik tulis in the Klang Valley which has a modern concept but has retained the featured motifs of flora. The use of modern colour compositions and subject matter as the idea and motifs are observed on the display of the batik tulis products at all three premises of these batik manufacturers.

\section{References}

Adi Taha (1991). Perkembangan Sejarah Awal Negeri Kedah, Berdasarkan Penemuan Bahan-bahan Arkeologi dlm Dokumentari Konvensyen Sejarah Negeri Kedah, .20-28.

Abdullah Mohamed (1978), Falsafah Dan Pemikiran Orang-Orang Melayu:Hubungan Dengan Islam Dan Kesenian,Kuala Lumpur Penerbitan Kementerian Kebudayaan , Belia Dan Sukan Malaysia.

Ahmad Dawa, M.N (2017), The symbolism of Batik from Kelantan,Malaysia:Its origin and transformation (Doctoral dissertation) Retrieved from ETHOS.

Ahmed, N. Y. N. (2015) Sumbangan Che Su dan keluarga kepada pembangunan perusahaan batik di Kelantan (Doctoral dissertation, University Malaysia Kelantan).

Akhir, N. H. M., Ismail, N. W., Said, R., Ranjanee, S., \& Kaliappan, P (2015) Traditional craftsmanship: The origin, culture, and challenges of batik industry in Malaysia. In Islamic perspectives relating to business, arts, culture, and communication (pp. 229237). Springer, Singapore. 
Arbaiyah Aziz. (2008) Menelusuri Tradisi Seindah seni Semurni Budaya dan Warisan Sepanjang Zaman,Batik Merbok ,MPH Group Publishing Sdn Bhd, Petaling Jaya,Selangor, PTAR UITM Shah Alam

Communication in Pahang.Jurnal Komunikasi Malaysian.

Dharmarajan, N., Aziz, A. A., \& Lokman, A. M. (2006). Archiving cultural heritage in Malaysia: The Nyonya kebaya. In Proceedings of the International Conference on Business Information Technology p. 13.

Drs,Biranul Anas (2008)Batik, Sekretariat Tim Penyusun Seri Buku Museum Grafika,Jakarta Pusat,Indonesia,PTAR UITM Shah Alam.

Fiona Kerlogue. (2004) The Book Of Batik,Archipelago Press, an imprint of Editions Didier Millet 121 Telok Ayer Street, Singapore,068590,PTAR, UITM Shah Alam.

Hassan,H,Birunal,A,N \& Santosa,I, (2013,April 4-7) Identity and values of Malaysian muslims among Women and their metaphor in fashion. Paper presented at the Asian Conference on Arts \& Humanities, Osaka, Japan.

Hidayat, J., \& Fatmahwaty, F. (2014) The Art and Sustainable Aspects of Natural Dyeing in Kanawida Hand Drawn Batik (Green Batik). IPTEK Journal of Proceedings Series, $1(1)$.

Hidayat, S. R. (2018) February. Innovation of Hand-Drawn Batik in Context of Tourism. In 4th Bandung Creative Movement International Conference on Creative Industries 2017 (4th BCM 2017). Atlantis Press.

Hussin,H,Husain,K,Pilus, A,H,Cheong K,M \& Mohd Yaacob ,N (2016) Innovation of Malaysia batik craft in arts . A reflection for vocational education. The Social Sciences, 11 (2),2893-2986.

Ismail, S. Z (1986), Rekabentuk Kraftangan Melayu Tradisi.Kuala Lumpur: Dewan Bahasa Dan Pustaka.

Itie Van Hout (2001) Batik Drawn in Wax, KIT publishers-Amsterdam, PTAR UITM Shah Alam.

Kari, R., Samin, A., \& Legino, R. (2018). The Sustainability's Motive and Design of Fauna in Malay Block Batik. In International Conference on Social Sciences,

Humanities, Economics and Law. European Alliance for Innovation (EAI).

Khairi, A., Hamid, S. E. A., \& Ismail, S. B. (2018) Penonjolan Identiti Budaya Melayu Kuala Lumpur Malaysian Institute of Marine Engineering Technology (UniKL MIMET),

Lumut, Perak. Wacana Seni Journal of Arts Discourse, 17.

Keith Critchlow (1996). Islamic Patterns:An Analytical And Cosmological Approach.Schocken Books,New York,USA.

Ku Zam Zam Ku Idris (1984), Nilai Keindahan Dalam Seni Kraftangan Melayu.Dewan Bahasa Dan Pustaka.

Mangifera, L. (2016) Pengembangan Industri Kreatif Produk Batik Tulis Melalui Value Chain Analysis.

Menerusi Aplikasi Batik dalam Pembuatan Bot Gentian Kaca (Fibreglass Boat) di Universiti

Mohamed A li, A.H (2009) Nilai Estetika Pada Motive Batik Tradisional Kelantan,Fakulti Seni Dan Muzik, Universiti Pendidikan Sultan Idris.

Moore, J.S (1994), How Designers Think, London, Butterworth Architecture.

Noorizan, M. F., Ramli, I., \& Nawawi, N. M. (2015) The Exploration Technique of Nature for Contemporary Batik Design. In International Colloquium of Art and Design Education Research (i-CADER 2014) (pp. 277-287). Springer, Singapore.

Perbadanan Kemajuan Kraftangan Malaysia (2017) Jenis-Jenis Batik,1 april, http://www.kraftangan.gov.my/maklumat-kraf-2/bidang -kraf/tekstil/batik/ 
Rahmah Bujang dan Nor Azlin (2002) Kesenian Melayu,Kuala Lumpur:Akademik Pengajian Melayu,Universiti Malaya.

Rahman, R. A. (2013) Cultural Conflict and Resolution Between Indonesia and Malaysia: The Government Effort to Respond Batik Climed by Malaysia in 2009 (Doctoral dissertation, President University).

Ramli, S, Rani, M.K.A.A \& Zamri, Exploration of batik lukis motives as a medium of art

Samin, M. A., Ramli, N. A., \& Legino, R. (2017). Designing batik with an alternative batik technique using wax application. Advanced Science Letters, 23(11), 1062910631.

Silah, S., Basaree, R. O., Isa, B., \& Redzuan, R. S. (2013). Tradition and transformation: the structure of Malay woodcarving motives in craft education. Procedia-Social and Behavioral Sciences, 90, 823-831.

Sardjono, A,Prastypo, B.A \& Larasti ,D.G (2015).Development of collective trademark for batik industry in Laweyan Batik's Village,Solo, Indonesia Law Review,5 (1),3350, doi:10.15742/ilrev.v5nl.136

Sekimoto, T (2003.) Batik as a Commodity and a Cultural Object. New York: Berghan Books.

Siti Zainon Ismail (1986) Rekabentuk Kraftangan Melayu Tradisi.Kuala Lumpur: Dewan Bahasa dan Pustaka.

Siti Zainon Ismail,Tekstil Melayu (1994) Fungsi Simbol dan Keindahan.Dalam Ismail Hussein, A.Aziz Deraman dan Abd. Rahman Al-Ahmadi, Tamadun Melayu Jilid Lima (hlm.2035-2055) Kuala Lumpur:Dewan Bahasa dan Pustaka.

Steelyana, W. (2012) Batik, a beautiful cultural heritage that preserve culture and support economic development in Indonesia. Binus Business Review, 3(1), 116.

Summers,D R (2014), Dictionary of contemporary English (5th ed) Harlow: pearson Longman. Wisnalmawati, W., Surachman, S., Rahayu, M., \& Hussein, A. S. (2015). Brand Prestige as Mediation Effect of Store Image on Store Loyalty (Study of Batik Tulis Store Customer at Yogyakarta Special Region). Australian Journal of Basic and Applied Sciences, 9, 635-641.

Yunus, N. A. (2012) Malaysian batik: Reinventing a tradition. Tuttle Publishing.

Yunus,N.A (2011). Malaysian Batik: Reinviting a tradition. Singapore: turtle publishing,

Zakaria, A \& Long A, S (2014), Titik Temu Antara Falsafah Dan Kehidupan Praktis.International Journal Of Islamic Through,3 37-44. 